\title{
Particle size characterisation of Holocene back-barrier sequences from North Atlantic coasts (SW Spain and SE England)
}

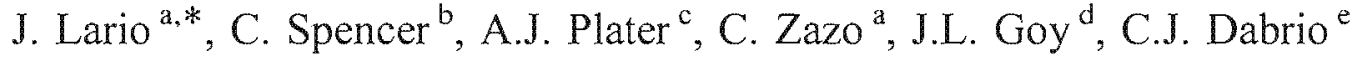

\begin{abstract}
In this paper, we present the results of bivariate plots of grain size parameters (mean against sorting) in the reconstruction of Holocene environmental change in coastal environments where barrier formation has had an important control on sedimentation. Sites on the North Atlantic coast with differing histories of climate, sediment flux, sea-level change and barrier integrity are investigated to determine the general efficacy of this bivariate parameter model in distinguishing between openand closed-basin conditions, and in reviewing the significance of aperiodic high-energy geomorphic events in controlling late stage back-barrier sedimentation.
\end{abstract}

Keywords: Particle size; Bartier coasts; Tidal sedimentation; Estuarine environment; Holocene; North Atlantic

\section{Introduction}

As a consequence of differential erosion, transportation and deposition, sediments laid down in different depositional environments may posses distinctive particle size distributions. By determining these particle size distributions it is, therefore, possible to hypothesise about the environment of deposition and so to utilise this technique as a tool for environmental reconstruction. A significant body of work during the latter part of the 20th century has attempted to establish the relationship between par- ticle size characteristics and depositional environment. However, Gale and Hoare (1991) suggest that this research has yielded confused and often contradictory results which is to be expected considering the complexity and overlap of the processes involved, and also lithological, mineralogical and source material controls. In attempting to determine the environment of deposition from particle size distributions, many workers have used a number of approaches, as described in the following section.

As a consequence of perceived limitations in terms of environmental reconstruction, particularly in comparison with many readily applicable micropalaeontological techniques, particle size analysis is a long-established and, perhaps, under-developed palaeoenvironmental technique. Indeed, the development of new instruments and methodological ap- 
proaches in particle size determinations have perhaps advanced at a greater pace than the complementary interpretative models (Syvitski, 1991). This has led to problematic issues in relation to intercomparison of new and established analytical methods (McCave et al., 1986; Syvitski et al., 1991; Duck, 1994; Konert and Vandenberghe, 1997; Beuselinck et al., 1998), e.g. mass $\%$ vs. volume $\%$ determinations, the crucial significance of particle geometry, comparison with previous results from more established methods (e.g., sieve and Andreason pipette), sedimentological classification relating to $\mu \mathrm{m}$-phi conversion, and the importance of sample preparation in influencing the results of sieve and pipette vs. laser granulometry. These are all far from insignificant issues.

In this paper, the results of laser granulometry are presented where grain diameter in SI units ( $\mu \mathrm{m})$ has been converted to the $\phi$-scale for interpretations which make reference to established approaches (Folk and Ward, 1957). A simple interpretative model is then applied in an investigation of deposition and sediment supply in back-barrier systems of variable integrity under the influence of Holocene sea-level rise. This is particularly important when considering the importance of the marine influence, as a balance between sea-level rise and sediment influx (Nichols, 1989), on back-barrier sedimentation (see reviews by Reinson, 1992; Roy et al, 1994; Cooper, 1994). In testing the general applicability of this interpretative model, it is important to examine contrasting barrier and backbarrier environments. Although barrier formation and progradation are favoured under conditions of stable or slowly rising relative sea level, barrier and backbarrier evolution are controlled by a number of processes that can be classified as geological factors and contemporary processes (Roy, 1984).

In addition to relative sea-level rise during the Holocene, sediment supply not only controls the rate and extent of lagoon infilling, but also influences barrier grain-size and morphology. Indeed, headland spits or bay barriers, like those under investigation here, rely on an alongshore supply of sediment and sufficient down-drift accommodation space in the form of an open embayment or shelf (Roy et al., 1994). Barrier grain size also controls the response of the barrier to factors such as sea-level rise, in that coarsegrained barriers are more prone to overstepping than sandy barriers due their slower response time (Carter and Orford, 1984). Wave energy also plays an important role in barricr location and sedimentation, and in the supply of sediment to the back-barrier environment, but Hayes (1979) regarded tidal range to be of utmost importance in back-barrier sedimentation. Greater tidal range results in stronger tidal currents and better developed tidal channels, and can influence factors such as the volume of flood-tidal deposition, tidal flat deposit thickness (Klein, 1972), and fringing saltmarsh sedimentation rate (Thorbjamarson et al., 1985). Hence, in this study, sites on the North Atlantic coast with differing histories of climate, sediment supply, sea-level change, coastal morphodynamics and barrier integrity are investigated to determine the general efficacy of a bivariate parameter model (Tanner 1991a,b) in distinguishing between open- and closed-basin conditions, and in reviewing the significance of aperiodic high-energy geomorphic events in controlling late stage back-barrier sedimentation.

\section{Methodology and use of particle size in characterisation of environments}

Cores were collected from lowland sites on the coasts of SW Spain and SE England in order to analyse the granulometric properties of successive sedimentary horizons, and to reconstruct the palaeoenvironmental history of coastal change in sites where barrier progradation across the mouth of an open estuary during the mid-to late Holocene has resulted in the formation of low energy environments which have fluctuated between open- and closedbasin conditions. High-resolution particle-size analysis of these samples was completed using a Coulter LS130 laser granulometer. The software provided by Coulter was used to calculate statistical parameters of mean, mode and median using the anthmetic method (Coulter Corporation, 1992). Measurements in $\mu \mathrm{m}$ were converted into the equivalent phi $(\phi)$ value (Krumblein, 1934). Skewness, kurtosis and standard deviation (=sorting), were calculated using the graphic expressions of Folk and Ward (1957) once the percentiles given by the Coulter laser were converted to $\phi$. Samples were taken from all the major minerogenic units within the cores, with sampling being gauged in order to characterise the upper, middle and lower sections of particularly thick units. 
In interpreting particle-size data, a number of approaches have been utilised, for example the use of summary statistics (mean grain size, sorting, skewness, and kurtosis) of particle-size distributions (Folk, 1974; Folk and Ward, 1957). These may then be plotted on bivariate scattergrams, for which a number of workers have identified graphic envelopes within which deposits of particular environments are plotted (Mason and Folk, 1958; Freidman, 1961, 1967, 1979a,b; Moiola and Weiser, 1968; Buller and McManus, 1972; Tanner, 1991a,b; Duck, 1994). Other approaches are reviewed in detail by Gale and Hoare (1991), who conclude that despite the extent and detail of these investigations, the attempts to determine the environment of deposition from particle-size data are of local application and are usually inadequate as a means of palaeoenvironmental reconstruction. Hence, particle-size data should only be used in conjunction with other evidence to determine the environment of deposition of a sediment.

Previous studies have tried to make environmental sense from bivariate plots of parameters that describe the sample size spectrum (Stewart, 1958; Friedman, 1961; 1967; Buller and McManus, 1972; Friedman and Sanders, 1978; Tanner, 1991a,b) and the success has been varied for several reasons, such as oversimplified discrimination, e.g. beach vs. river where dunes and other depositional settings are ignored (Socci and Tanner, 1980). From these results, it is clear that no universal models exist to distinguish past deposition environments using these graphic approaches (McManus, 1988). Tanner (1991a), however, has utilised bivariate plots of particle-size data to investigate the environment of deposition by plotting mean grain size against sorting. Tanner (1991a) acknowledges the problems that exist using such plots and has examined methods that may assist in the resolution of the environment of deposition. The method presented by Tamner (1991a) is investigated here on sediments from two coastlines. In this study, we use only mean and sorting in order to correlate these parameters with the depositional evolution of Holocene estuarine and back-barrier environments. This type of bivariate plot has been used by Tanner $(1991 \mathrm{a}, \mathrm{b})$ in an attempt to separate "large new supply" (river or closed-basin) from wimnowing environments (beach and dune). As it is generally accepted that mean grain-size and sorting are hydraulically controlled (Griffiths, 1967), these parameters can be positively correlated with the energy of the environment and the degree of sediment processing, as has been used by Long et al. (1996) and Lario et al. (2000).

\section{SW Spanish Atlantic coast: Gulf of Cadiz}

This coastline is a wave dominated mesotidal coast with southwesterly prevailing winds and a west-toeast littoral drift that becomes re-directed to the southeast near the Strait of Gibraltar due to coastal orientation. Sediment sources are from the sandy cliffs of the Algarve coast ( $S$ Portugal) as well as from the main rivers that debouch into the Gulf of Cadiz. In general, the main morphosedimentary systems in this littoral zone include marshlands and spit bars which are the result of progressive infilling of the Holocene estuaries due to the development and progradation of spit bar systems at their mouths.

Studies of the Holocene evolution of morphosedimentary units as well as the depositional sequences of the estuaries have enabled reconstruction of the evolution of these barrier estuaries for the Late Pleistocene and Holocene (Zazo et al., 1994, 1996; Lario et al., 1995; Goy et al, 1996, Lario, 1996; Rodríguez Ramírez et al., 1996; Dabrio et al., 1999). In these evolutionary models, it is proposed that the progradation of the spit-bar systems developed in two main phases (composed of several morphosedimentary units denoted by the letter $\mathrm{H}$ and a number) separated by a large erosional gap related to climatic instability. Radiocarbon data, corrected for the reservoir effect, date this erosional gap to between 2600 and 2350 years BP (Lario, 1996). After that time, the second accretionary phase started and progradation of large systems of emerged spit-bars along the coastline reduced the connection of the estuaries with the open sea, resulting in the progressive formation of lagoons until the coast reached its present stage dominated by tidal tlat and marsh environments (Goy et al., 1996). In this second phase, a further erosional gap has also been identified between morphosedimentary units $\mathrm{H}_{3}$ and $\mathrm{H}_{4}$ (as defined by $\mathrm{Zazo}$ et al., 1994), which has been dated to between 800 and 500 years BP.

The Late Pleistocene-Holocene sequence of coastal evolution in this region is summarised here. Around ca. 18000 years BP, the sea level was be- 
(a)

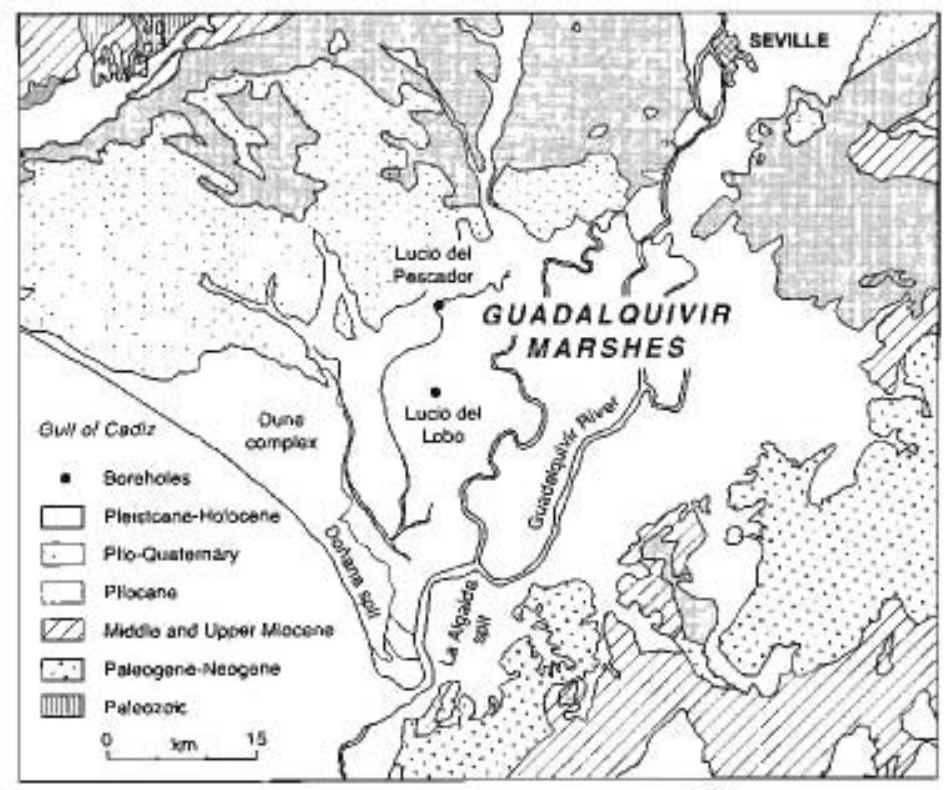

(b)
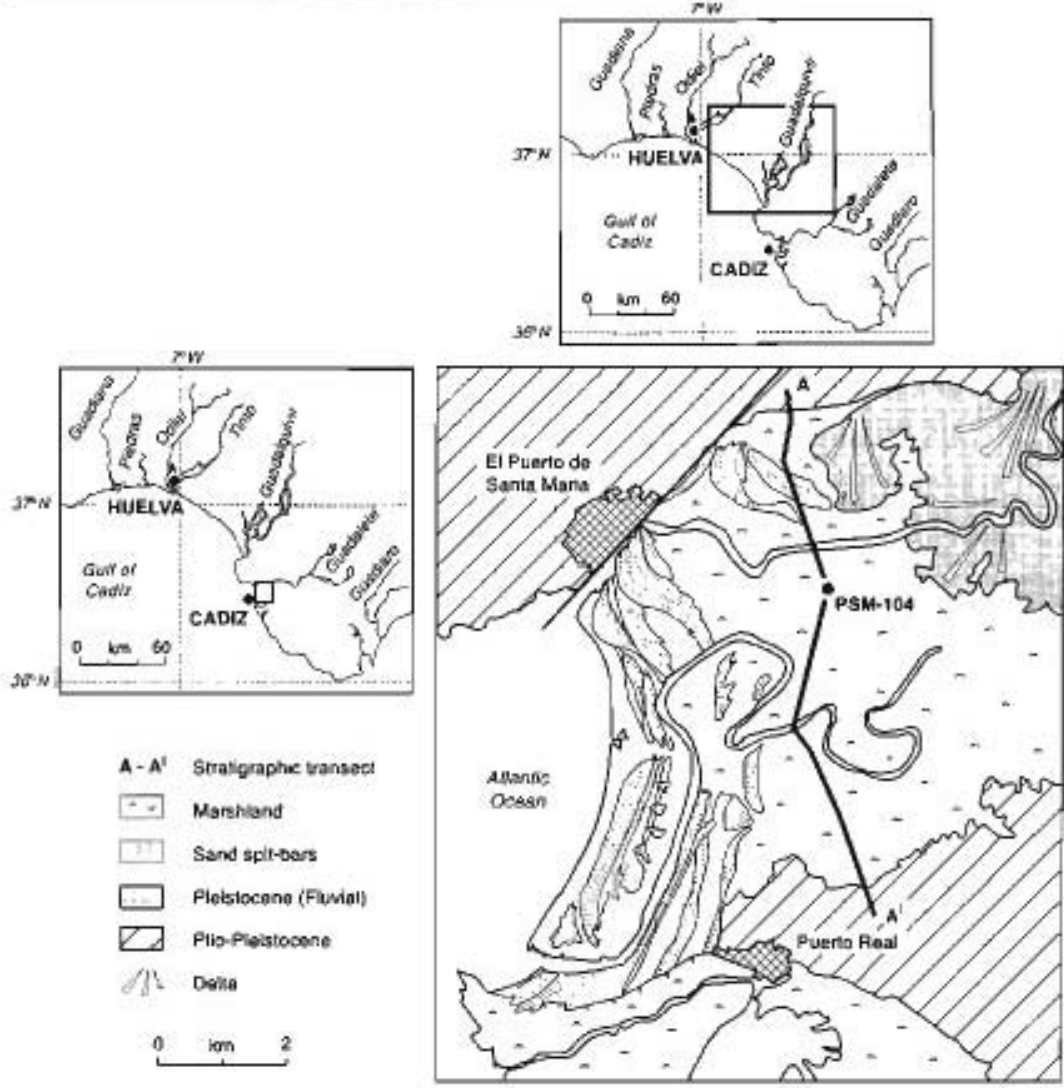

Fig. 1, Location of spin barner sysiems in SW Spain, including (a) the location of cores Lucio del Lobo (LL) and Lucio del Pescador (LP) from the Guadalquivir marshes, and (b) the location of core PSM-104 on the stratigraphic transeet across the Guadalete marshes. (Modified from Dabno et al., 1999). 
tween -125 and $-120 \mathrm{~m}$ relaive to the present level (Hernández Molina el al., 1994). This was followed by a rapid rise after the Lare Glacial maximum. Al ca. 9600 years BP, a deceleration in the rate of sea-level rise occured, as recorded by organic and peat deposits and gravels and shells lags found in various cores from the Guadalete and Tinto-Odiel esiuaries (Dabrio et al. 1995; Goy el al., 1996; Lario, 1996; Zazo et al., 1996; Dabrio et al., 1999), This deceleration has been related to the Younger Dryas event (Lario, 1997) and to the sea-level stillsiand that has been registered during this event in the North Allantic (Mayewski, 1994; Stanley, 1995). After that lime, a renewed acceleration in the rate of sea-level rise took place until the maximum landward advance of the marine influence was reached at ca.7000-6000 years BP (Lario, 1996; Dabrio el al., 1999). Following this, a series of negative and posinive oscillations in sea level occurred which, logether with the sediment dynamics at that time, favoured the development of spit barrier systems (Zazo ef al., 1994; Lario et al. 1995; Lario, 1996).

\subsection{Back-barrier deposits from the Guadalquivir marshlands}

The Guadalquivir marshlands consist of a large tidal flat and marsh complex enclosed by the barrier system of the Donana and La Algaida spits (Fig. la). The entire area is also partially covered by an aeolian dune complex. The morphosedimentary unirs presen in this area include unirs $\mathrm{H}_{3}$ and $\mathrm{H}_{4}$ in Donana spir and units $\mathrm{H}_{2}, \mathrm{H}_{3}$ and $\mathrm{H}_{4}$ in La Algaida spit (Zazo er al., 1994; Lario el al, 1995; Lario, 1996; Rodriguez Ramirez el al, 1996). The second progradation phase has been the best preserved in this area. Moreover, unit $\mathrm{H}_{4}$ appears to have prograded rapidly during the last 400 years due to the high progradation rates resulting from floods and storms, as well as mining and forestry activity in the adjoining catchment area (Lario et al., 1995). Although stratigraphic investigations have been undertaken on this site, the overall partern of Holocene sedimentation has nor been established fully. Hence, cores from Lucio del Lobo and Lucio del Pescador are considered only as a contribution to a growing body of

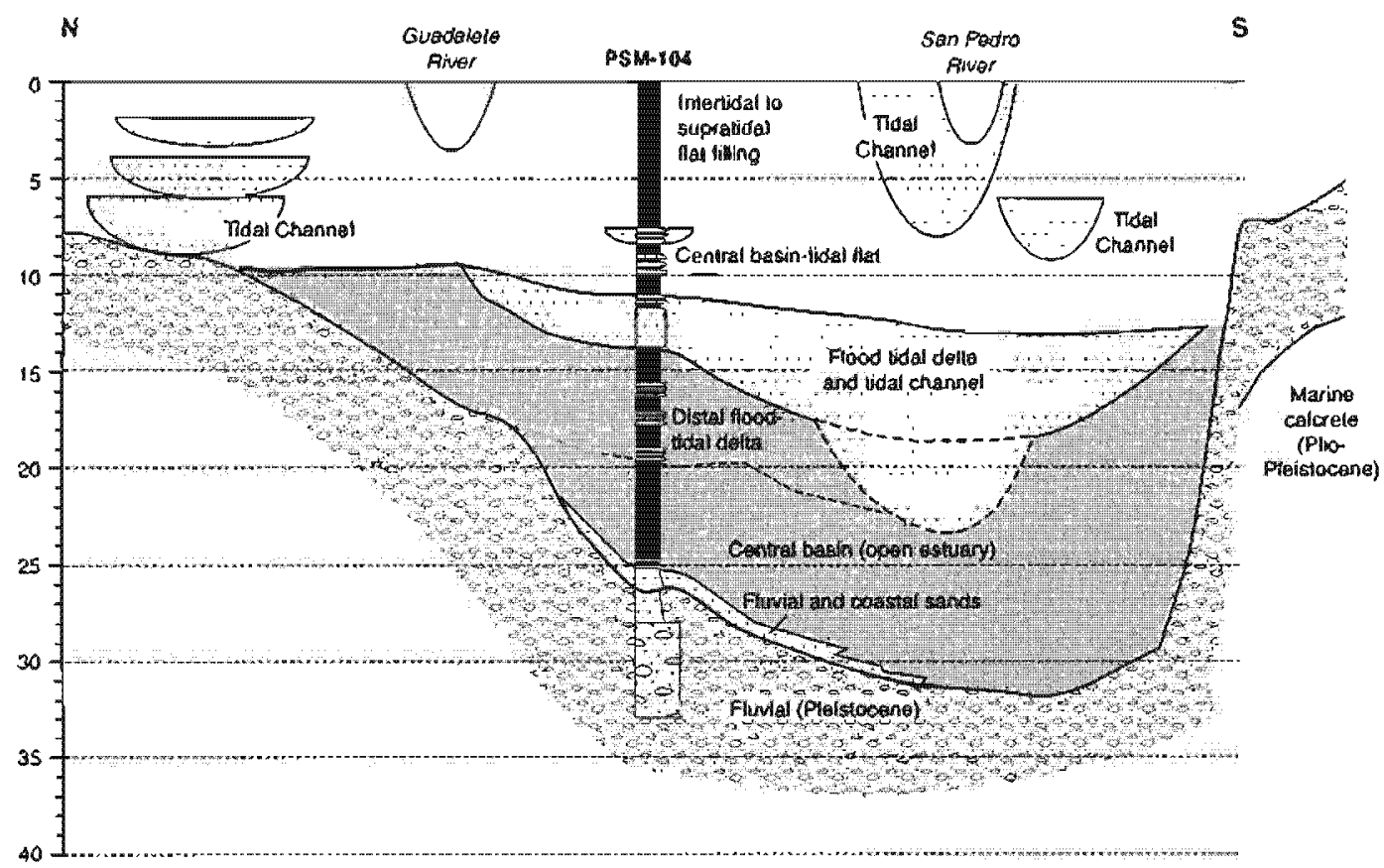

Fig. 2. Stratigraphy of core PSM-104 in relation to the palseoenvironunents identifiod from the Guadaleie marsh stratignaphic cross-section. (Modified from Dabrio et al., 1999 ). 
palaeoenvironmental data on the Holocene evolution of the Guadalquivir marshlands.

\subsection{Back-barrier deposits from the Guadalete marsh- lands}

The Guadalete marshlands consist of a large tidal flat and marsh complex enclosed by Valdelagrana spit barrier system (Fig. 1b). The Bay of Guadalete underwent tectonic subsidence during the Quatemary and faulting favoured the occurrence of the Guadalete river valley opening to the west (Zazo et al., 1994). River incision took place during the Last Glacial period, and during Post-Glacial sea-level rise the seaward reaches of the valley were inundated. A wave-dominated estuary was formed which became progressively enclosed by the barrier system (Goy et al, 1996; Lario, 1996; Dabrio et al., 1999). The sedimentary sequence includes Late Pleistocene-Holocene deposits, from which it is possible distinguish pre-estuarine fluvial sediments and Holocene coastal sediments ranging from open marine to marshland environments (Fig. 2). Once the maximum Holocene transgression had taken place in this area, the spit barrier began to develop and more closed-basin conditions ensued, resulting in the eventual infilling of the estuary. The morphosedimentary units recognised in Valdelagrana spit complex include units $\mathrm{H}_{2}$ (late first progradation phase) and $\mathrm{H}_{3}$ and $\mathrm{H}_{4}$ (second progradation phase) (Zazo et al., 1994; Goy et al., 1996; Lario, 1996; Dabrio et al., 1999).

\section{Southeast England: the Romney Marsh Area}

Romncy Marsh is situated in the southeast of England on the coastline of the eastem English Channel, and encompasses the coastal lowland environments of Romney Marsh proper, Walland Marsh, Denge Marsh and the adjoining valleys which lie to the west and northwest. At the seaward margin of the marsh sediments are the gravel ridges of Dungeness Foreland, the most extensive gravel complex in the United Kingdom (Carter et al., 1989). The dominant water movement in the English Channel is controlled by tides, except in the shallow nearshore where the predominant winds from the southwest are influential (Long et al., 1996). This results in nearshore west-to-east longshore drift
(Green, 1968). The tidal regime in the Romney Marsh region is macrotidal (spring tidal range ca. $5.9 \mathrm{~m}$ ), with the height of mean high water spring tides at Dungeness being $+4.03 \mathrm{~m}$ OD (Admiralty Tide Tables, 1994). The 1-in-100-year maximum tide adds a further $25 \%$ to the spring tidal range (Graff, 1977) and the 1-in-50year storm surge is $1.75 \mathrm{~m}$ (Crease, 1983).

The gravel barriers have played a critical role on the deposition of Holocene coastal sediments in this region, providing quiet water back-barrier and barrier estuary environments thus enabling fine-grained sedimentation. It has been demonstrated (Spencer, 1997) that an initial protective gravel barrier extended across Rye Bay from southwest to northeast from Fairlight, through Broomhill to Scotney Marsh (north of Lydd). This initial barrier is believed to have migrated onshore as a swash-aligned barier with rapidly rising sea-level during the early Holocene (Long et al., 1996), until it reached the cliffline in the west, probably at Fairlight (Eddison, 1983). It appears from the initiation of peat forming communities in the back-barrier environment that the protective gravel barrier was in place between 6850 and $5700 \mathrm{cal}$. years BP (Long and Innes, 1995). Once anchored, sedimentation in the region of the resulting back-barrier environment changed significantly. Previously, marine sand flats had prevailed (Long et al., 1996), but these sand flats changed to marine-brackish mudflats which became sub-aerially exposed in sheltered areas, leading to colonisation by vegetation as early as $7180-$ 6445 cal. years BP (Waller et al., 1988). At that time, the sedimentation rate in the back-barrier environment exceeded the decelerating rate of sea-level risc (Spencer et al., 1998), allowing peat-forming conditions to spread outward across the back-barrier, reaching the mid-marsh areas by ca. $5000 \mathrm{cal}$. years BP (Long and Innes, 1995) and the fore-marsh areas by ca. 3000 cal. years BP (Spencer, 1997; Spencer et al., 1998). Following this time, an increase in the marine influence in the back-barzier environment is recorded by a reversal of the vegetation succession across the marsh; first as a rise in the water table and, eventually, as a return of sedimentation under marine conditions.

\subsection{Back-barrier deposits of Scotney Marsh}

Within the back-barrier environment of Romney Marsh, the Scotney Marsh area was selected for 
detailed study, as it is locared at the barrier/backbarrier interface (Fig. 3a). I was believed, therefore, that such a site would be most sensitive to changes in sedimentary conditions driven by sea-level changes and/or barrier breaching/fomation.
Detailed palaeoenvironmental reconsmuclion has demonstrated that four general sediment types prevail across the area (Fig, 3b). Basal gravel makes up the lowermost deposit throughout the area, in which two morphological ridge features can be identified

(a)

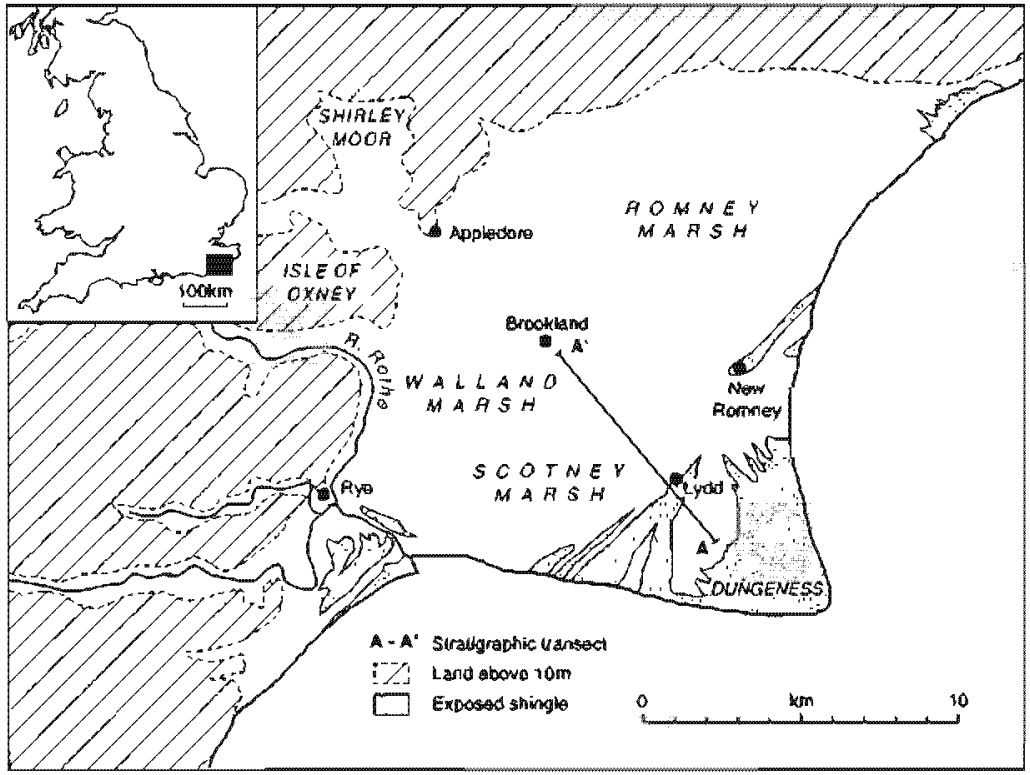

(b)

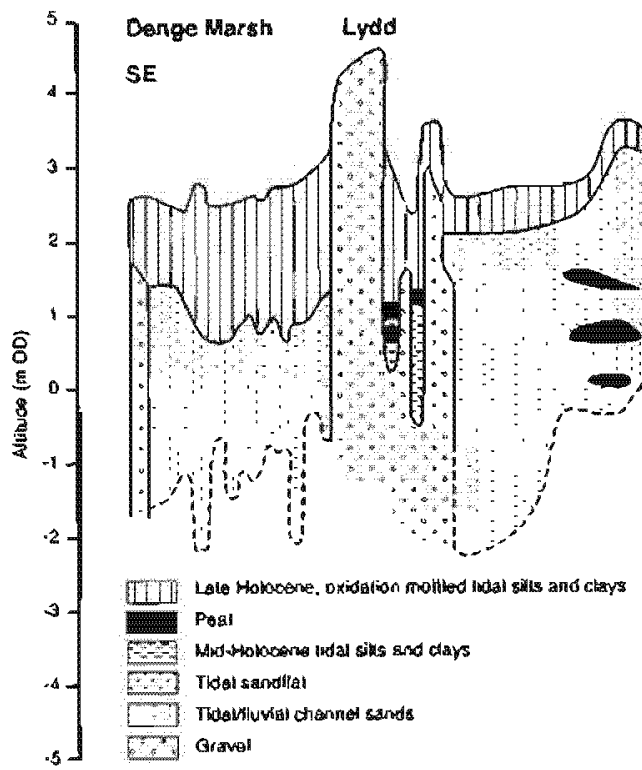

Orewkland

NW

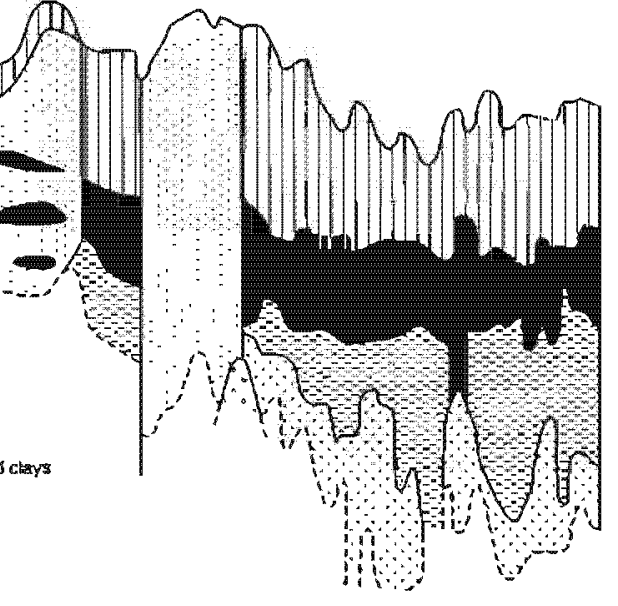

Fig. 3. (a) Location of the Romney Marsh bamier and marsh complex in SE England, and (b) srratigraphic cross-section across Scotney Marsh. Cores $G 60$ and AY 17 lie in the region immediacely northwest of the Lydd gravel bamer. 
(Spencer, 1997). Overlying the gravel are a series of sands, silts and clays deposiled on tidal Mals initially under marine condilions, becoming more brackish upward. These sediments pass transitionally upward into peary-clay and then peat. As the marine influence became furnher removed by ca. $3200 \mathrm{cal}$. years $\mathrm{BP}$ in

(a) LUCIO DEL LOBO

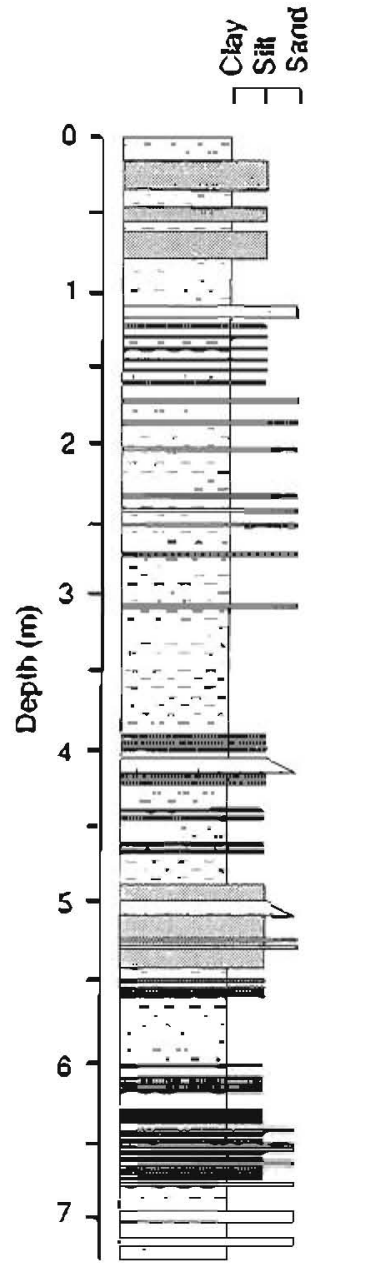

the Scolney Marsh area, Phragmites saltmarsh, then freshwater reedswamp and eventually sedge ren developed (Spencer, 1997: Spencer el al., 1998). An increase in the marine influence across Sconey Marsh after ca. 2800 cal. years BP is preserved in the vegetalion record, first by a rise in the water table

(b) LUCIO DEL PESCADOR

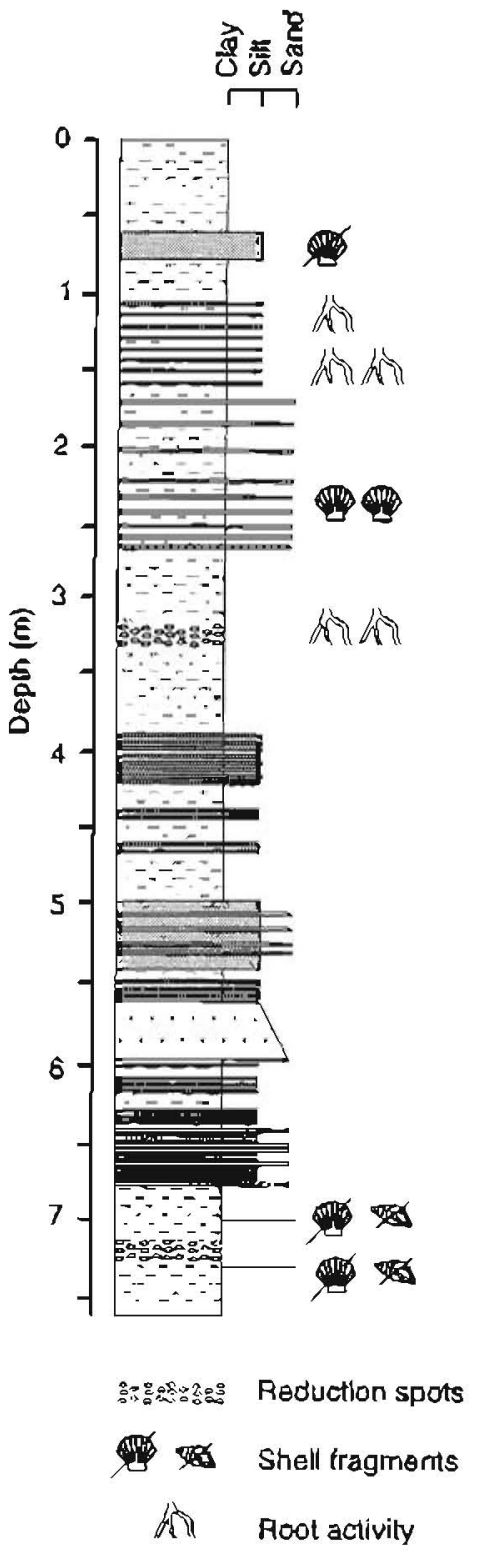

Fig. 4. Stracigraphic logs for Guadalquivir corss LL (a) and LP (b). (Maditiod from Lario, 1996). 
and then by a subsequent return of saltmarsh conditions and eventual inundation of the peat and returm to minerogenic sedimentation. The sedimentary unit overlying the peat in Scotney Marsh is an oxidationmottled orangey-grey silty-clay to silty-sand. This sediment appears to have been deposited on a brackish mudflat becoming a more marine sandflat upward, although palaeoenvironmental indicators are generally absent from the upper metre or so of this unit. Locally, tidal and/or fluvial channel sands can be found where the late Holocene back-barrier drainage system has etched into the marsh stratigraphy.

The sediments in Scotney Marsh preserve a record of environmental changes, the causes of which are not certain but are believed by Spencer (1997) to be due to changes in the rate of sea-level rise relative to the rate of sedimentation (Nichols, 1989). This may be due either to temporal variations in the rate of sealevel rise or to changes in sediment supply. It is also possible that degradation of the gravel barrier or barrier breaching/overtopping may have brought about an increase in the marine influence during the late Holocene, but no unequivocal sedimentary evidence of these aperiodic events has been identified.

\section{Particle size characterisation and coastal evolution}

\subsection{Guadalquivir}

Two cores were obtained from the marsh sediments by means of a combination of Eijkelkamp percussion drill and Russian corer. Core LL from Lucio del Lobo (Fig. 4a) reached a depth of $7.30 \mathrm{~m}$, and core LP from Lucio del Pescador (Fig. 4b) extended to $7.60 \mathrm{~m}$. Core LL was sampled every $20 \mathrm{~cm}$, whilst core LP was sampled every $10 \mathrm{~cm}$. Because the bottom of core LP has been dated to ca. 2500 years BP (Goy et al., 1996; Lario, 1996), this late Holocene sequence was considered to include the second progradation phase recorded in this littoral area.

Using the domains defined by Tanner (1991a), the combined mean grain-size and sorting plot (Fig. 5) shows that the majority of the sediments were deposited under closed-basin conditions, which may be interpreted as the final stages of the evolution of the partially closed estuary into tidal flat and marshes

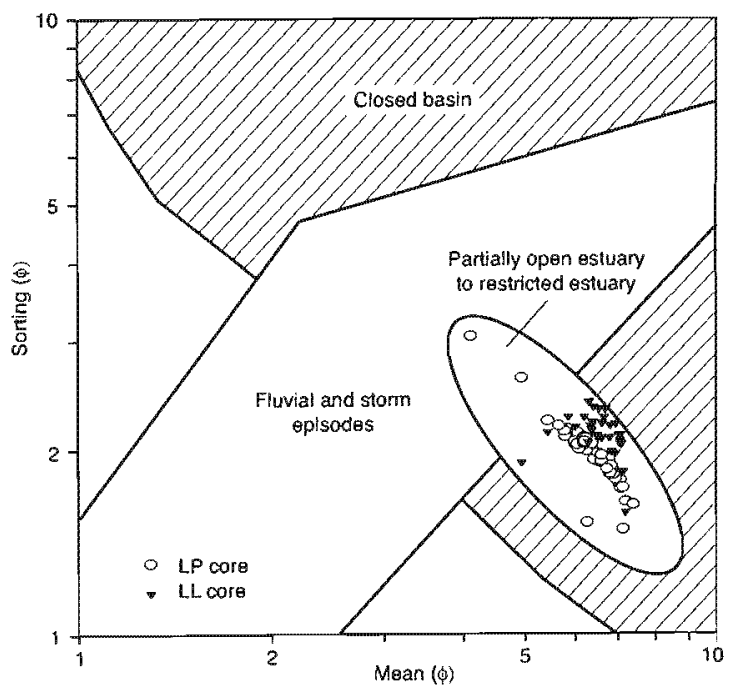

Fig. 5. Bivariate plot of mean grain size against sorting for cores LP and LL (Guadalquivir marshlands).

once the barrier system was well developed. Some episodes can be linked with high-energy conditions (storms, floods and even tsunamis) from the input of coarse sediments into the inner estuary during this infilling phase (Lario, 1996; Lario et al, 2000). These episodes are characterised by an increase in the mean grain size as well as a marked decrease in sediment processing, as indicated by both the mean/median ratio and sorting. Because these characteristics are also indicative of a fluvial environment, the fluvial domain, as defined by Tanner (1991a), includes the aperiodic flood events described above.

\subsection{Guadalete}

A total of 93 samples were obtained from a $28-\mathrm{m}$ deep core (PSM-104) in the Guadalete estuary (Fig. 6). The core includes a continuous sequence of Late Pleistocene-Holocene sediments. From lithological and particle size characteristics, seven levels (with some sub-levels) have been identified and are associated with different sedimentary environments (Lario, 1996).

Levels $a_{0}$ and $a_{1}$ (sands and gravels between depths of ca. 32 and $26 \mathrm{~m}$ ) correspond with fluvial sediments from the Late Pleistocene which were deposited until at least the beginning of Post-Glacial transgression. Sediment deposition was favoured under a lower sea-level regime than at present, i.e. 


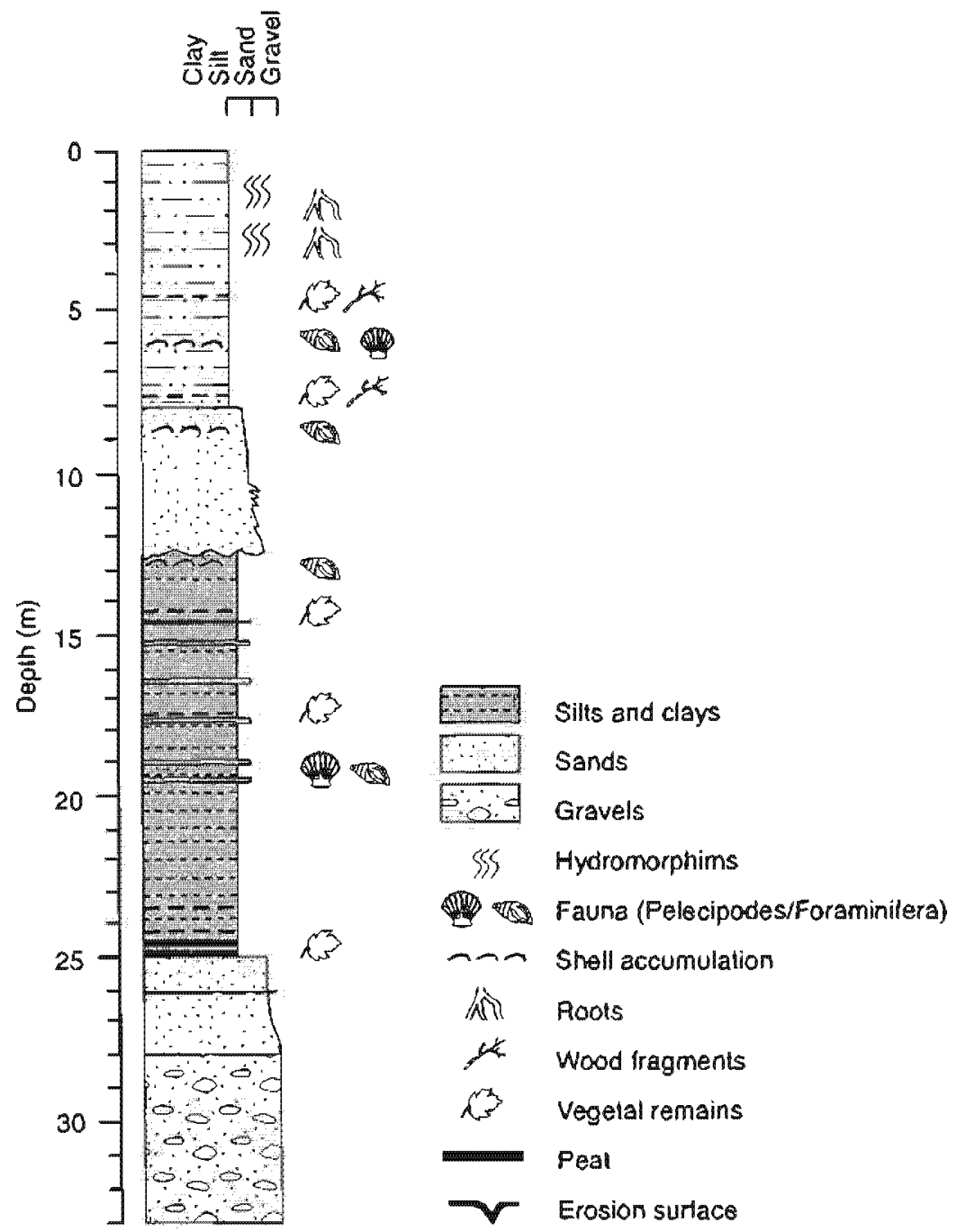

Tig. 6. Straligraphic log for Guadalele core PSM-104. (Modified from Goy el al., 1996).

more than $100 \mathrm{~m}$ lower at ca. $20,000-18,000$ years $\mathrm{BP}$, when the shoreline was localed near the presentday shelf break. Al the same lime as this shoreline migrated towards the open sea, a readjustment in nuvial equilibrium levels took place, with deposition of pebbles, fluvial sand and flooding clays (Kraft, 1971: Posamentier and Vail, 1988). Level $a_{2}$ includes a series of sands between depths of 26 and $25 \mathrm{~m}$ with a different origin than the underlying sediments (as interpreled from environmental magnetic properties;
Lario, 1996), and have been interpreted as nearshore sands and sills related to a transgressive sequence. These sediments were deposited during the rapid sealevel rise that took place berween ca. 16,000 and 9000 years BP. Indeed, this deposition of nearshore sands as a result of a rapid shoreline migration towards to the hinterland is well documented (Curray et al., 1969; Roy and Crawford, 1981; Roy el al., 1994; Stanley and Wame, 1994; Warne and Stanley, 1995; Kuaft and Chrzasrwoski, 1985). 
Level $b_{1}$ is a peat level at the base of a regressive event (at ca. 24.5-m depth) and is related to a deceleration in sea-level rise (ca. 9000 years BP, from Dabrio et al., 1995). Level $b_{2}$ is an overlying sequence of silts and clays with sand lenses and fragments of marine shells, and has been interpreted as an open estuary facies (Goy et al., 1996; Lario, 1996; Dabrio et al., 1999).

Level c starts with a storm unit at a depth of approximately $13 \mathrm{~m}$, characterised by coarser material input, marine shell fragments and poor sorting, and is interpreted as a stillstand or even the beginning of a slight sea-level fall (Lario, 1996). This is confirmed by level $d$, which is a fluvial sand at ca. $12-\mathrm{m}$ depth in which poorly preserved shell remains are associated with a drop in $\delta^{13} \mathrm{C}$ related to a fresh water input (Lario, 1996; Dabrio et al., 1999). This short-lived event (ca. $6000-5800$ years BP) was followed by the deposition of levels $\mathrm{e}$ and $\mathrm{f}$ which preserve the evolution from an estuary to a deltaic environment (Dabrio et al., 1995; Goy et al., 1996).

At a depth of approximately $8-\mathrm{m}$ level, $g_{1}$ shows the beginning of the infilling of the estuary, with an increase in fine particles and a reduction in sand, which had become trapped in the spit barrier. Level $g_{2}$ indicates a stillstand in sea level or a gentle fall (Roy et al., 1994), or at least that the supply of sediment was higher than the rate of sea-level rise, which induced the progradation of the spit barrier (Lario, 1996).

Using the bivariate plot for a series of samples from these levels (Fig. 7), it would appear that levels $a$ and $d$ correspond with the "net" fluvial environment field defined by Tanner (1991a). Sub-level $a_{2}$ is interpreted as a transitional deposit between the combined fluvial levels $a$ and $d$ and the estuarine deposits which correspond to levels $b, c, e$ and $f$. These deposits are used to define a new field (Lario, 1996; Lario et al., 2000) that corresponds to the transition between openand closed-estuary environments, with some episodes of a renum to open marine conditions (probably related to aperiodic breaching of the barrier units (Lario, 1996). Level $g$ records the total closure of the estuary (being contained entirely within the closed-basin field). In addition, there are some storm or even tsunami episodes, as have been observed in the Guadalquivir marshlands, which are characterised by the input of coarse material and shell fragments into the

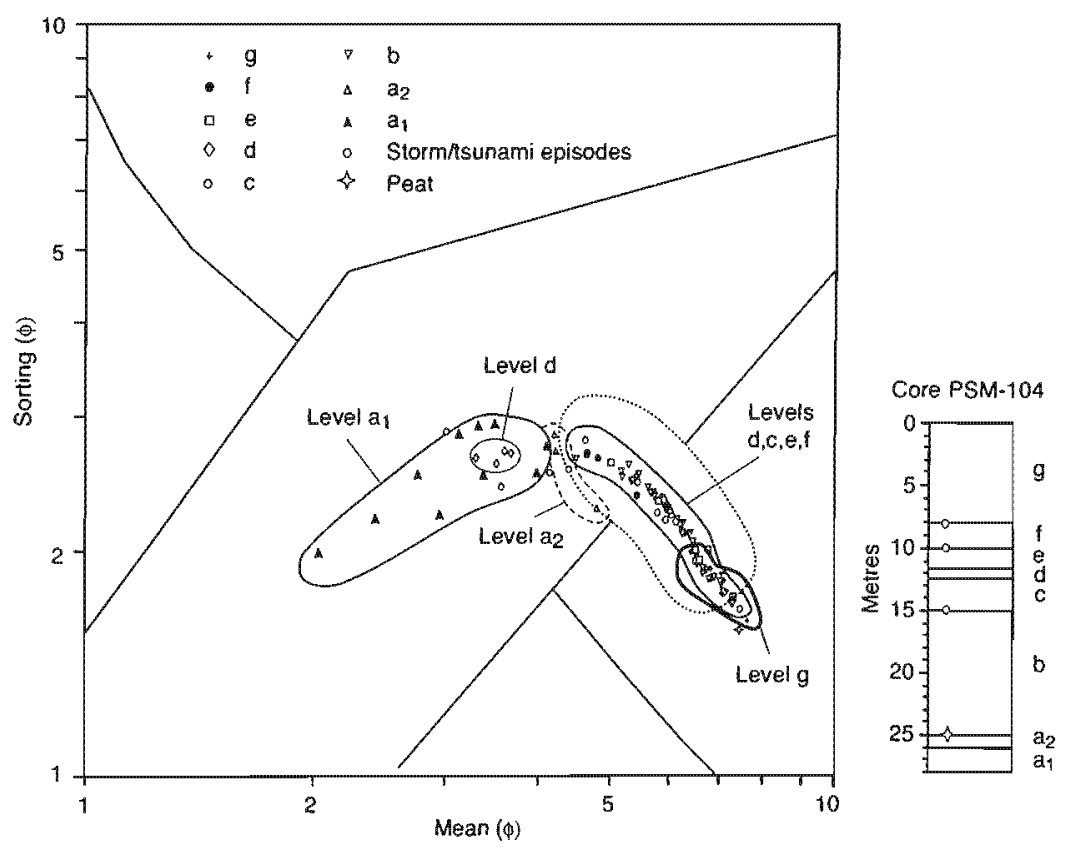

Fig. 7. Bivariate plot of mean grain size against sorting for core PSM-104 (Guadalete marshlands). 
estuary. Indeed, if the bivariate plot was interpreted in terms of changes in the hydraulic conditions (Fig. $10 \mathrm{~b}$ ), these episodes show a marked jncrease in the depositional energy of the environment.

\subsection{Scotney Marsh}

Particle-size analyses were carried out on two typecores from the Scotney Marsh area (cores AY 17 and $G 60$ ). These cores were selected to represent the sediments typical of the Scoiney Marsh area (Spencer, 1997). Core AY 17 was situated in the main backbatrier environment, proximal to the initial protective gravel banier, behind which the marsh sediments were deposited. Core G60 was sampled seaward of the initial protective gravel banier in what Spencer (1997) has referred to as the Scomey Marsh trough. This morphological feature appears to have been a (a) AY17

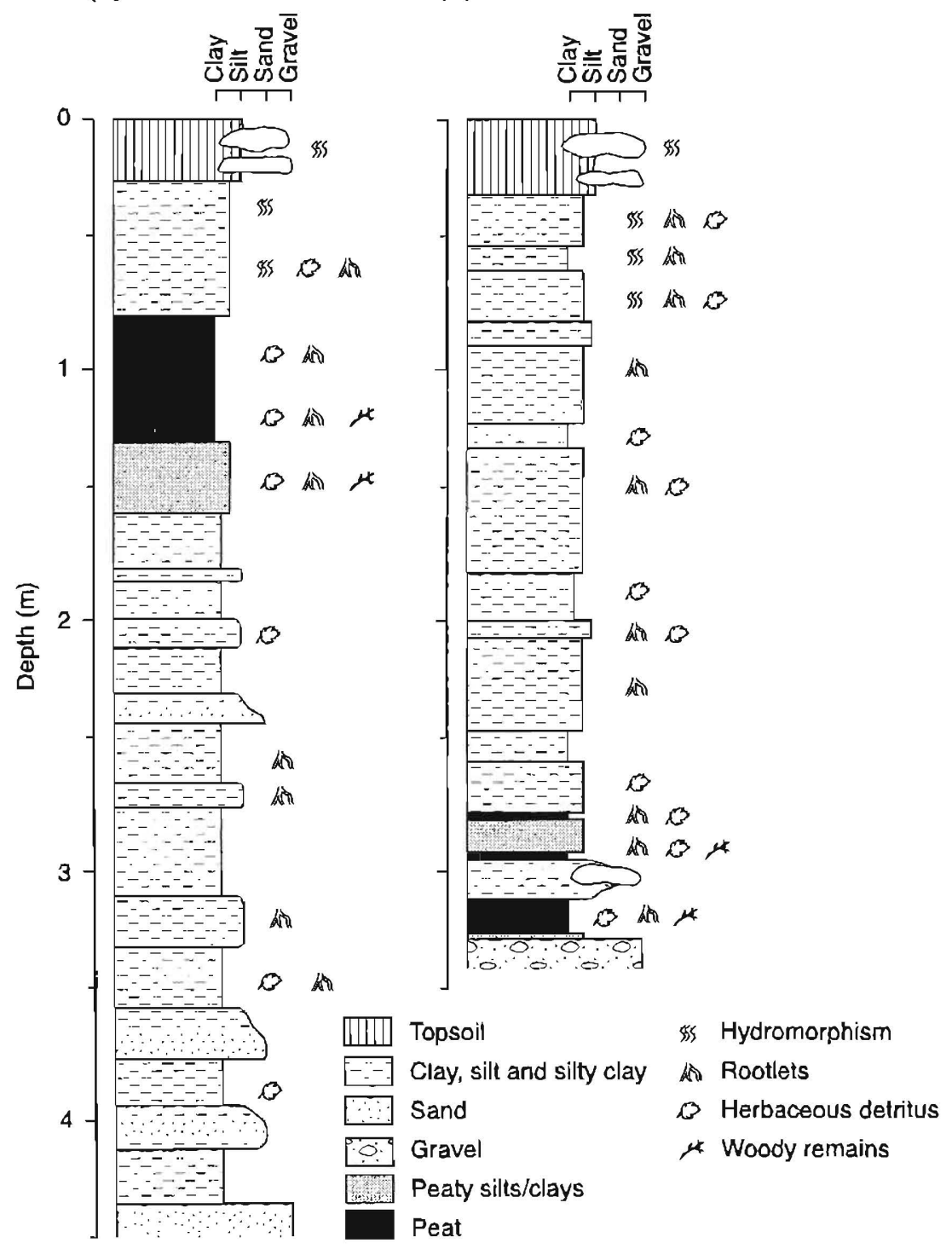

Fig. 8. Stratigraphic logs for Romney Marsh cores AY17 (a) and G60 (b). 
tidal rough between the initial gravel barrier and another, which was deposited against its seaward slope, thus creating a sheltered environment with open access to the sea.

\subsubsection{Core AYI7}

At the base of the blue-grey tidal silts and clays (below a depth of ca. $3.70 \mathrm{~m}$ ) (Fig. 8a), lenses of relatively coarse grained, well-sorted, fine sands are indicative of deposition under wave action. However, the absence of a consistent negative skew is somewhat contradictory to this. Indeed, the environment of deposition is suggested to have been an open tidal inlet on the verge of closure from the bivariate plot of mean grain size against sorting (Fig. 9), where they cluster on the closed-basin/river transition. The notable exception to the overall pattern is that a number of sediments from the base of the core are coarser and are more indicative of a relatively high-energy beach environment in which wave action dominated. The sediments above these sandy units, i.e. the main body of the silts and clays beneath the peat, appear well within the closed-basin envelope and migrate progressively toward the boundary with the river environment envelope upward through the core. It would appear, therefore, that the back-barrier environment was becoming more enclosed, and possibly shallower, as

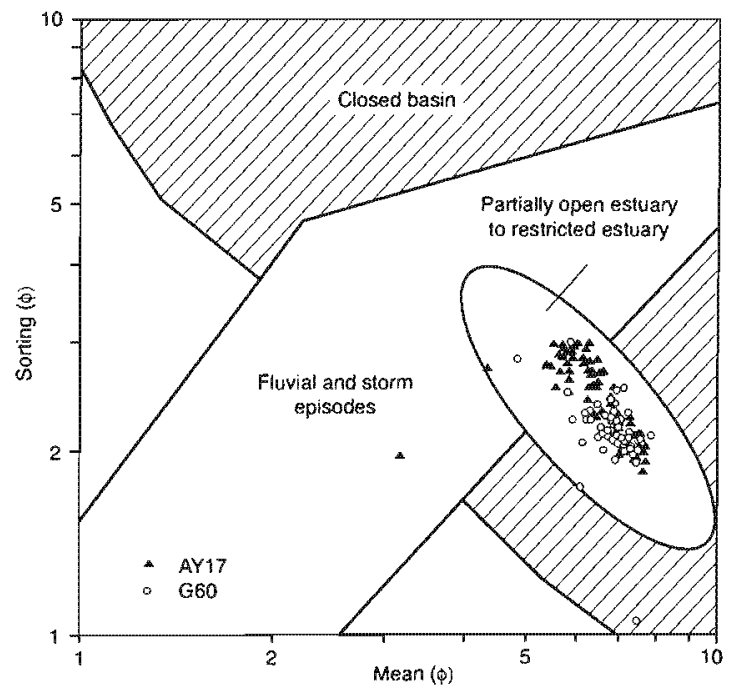

Fig. 9. Bivariate plot of mean grain size against sorting for cores AY 17 and G60 (Romney Marsh). a reduction in the linkage with the open sea occurred as a consequence of barrier progradation. This enclosure was probably associated with the enhanced supply of sediment from the adjacent catchments.

The particle-size distributions of the silts and clays beneath the peat and, indeed, the peaty clay (Fig. 8a) preserve changes in water depth and tidal flow velocity which are represented by subtle variations in the sorting and mean grain size. Sediments from Denge Marsh with similar sedimentary characteristics have been described by Plater (1991) as tidal muds, whilst those samples with a more symmetrical particle size distribution are considered to represent deposition near to the limit of the tidal influence, as proposed by Long et al. (1996).

\subsubsection{Core $G 60$}

Some very gradual changes in the particle size characteristics of core $\mathrm{G} 60$ (Fig. $8 \mathrm{~b}$ ) can be identified. For example, the mean grain size increases slightly up-core, i.e. very fine silt becoming fine silt, in parallel with a subtle upward change from predominantly near symmetrical distributions to fine-skewed and occasionally strongly fine-skewed samples (Spencer et al., 1998). Significantly, two samples in core $\mathrm{G} 60$ contain gravel and, hence, record aperiodic high-energy events, which led to the re-mobilisation or disturbance of the gravel ridges. Above the lower peat unit in $G 60$, the control of sea-level rise on the nature of sedimentation is indicated by a reversal of the vegetation succession prior to marine inundation. This eventually resulted in the deposition of a very well-sorted, coarse to very fine silt, probably laid down in mudflat conditions. Upwards, this relatively low energy environment was punctuated occasionally by high-energy events, which led to the deposition of the silts and gravels. The particle-size characteristics indicate an environment of deposition exposed to the open sea, although deposition appears to have been close to the tidal limit.

Throughout the deposition of tidal silts and clays above the peats, subtle variations in the particle-size distributions of the sediments indicate that slight variations in the tidal flow velocity and water depth occurred in the Scotney Marsh trough, although no clear evidence of wave action or reworking has been identified. The overall trend indicates that the sediments were deposited in an environment of progres- 
sively higher energy, but with the continued deposition of fines at high water. Again, using the model of Tanner (199/a), Fig. 9 shows that the sediments from G60 exhibit a similar trend to those of core AY 17 in that they cluster across the boundary between the closed-basin and river envelopes. In this case, however, the "river" environment is more likely to be a tidal channel, as discussed in Spencer (1997). This would require some reclassification of Tanner's model.

The use of bivariate plots in the Scotney Marsh example assists in the interpretation of the environment of deposition in the context of barrier integrity and sediment flux. For both cores, the bivariate plot envelopes illustrate that the sedimentary environment moves away from the closed basin toward the river envelope upward through the stratigraphic column. This suggests that the environment was becoming either more open to the influence of the sea in the form of a current swept tidal channel, or perhaps that the environment was becoming more river-dominated in a terrestrial setting. It is proposed that sedimentation in the back-barrier environment became more dominated by water flowing in and out of the backbarrier environment within river-like tidal channels, i.e. uni-directional flows which periodically change direction, bringing a fresh influx of sediment with the incoming flood tide. In addition, the bivariate plots demonstrate that little or no sedimentation occurred in the Scotney Marsh area as a result of either barrier breaching/overtopping or high-energy river inputs. This is important as it provides additional information about the predominant sedimentary influences in the back-barricr environment of Scotncy Marsh.

\section{Discussion}

In general, four sources of sediment have been described in estuarine systems (Luternauer et al., 1995): minerogenic sediments derived from marine waters and fluvial waters; organic sediments; and redistribution of both types of sediment within the estuary itself. The dominance and relative contribution of each of these sources have been discussed by Allen (1990) and Shi (1993) who found that the organic component is considered to be small compared with the input of minerogenic sediment. It is difficult to attribute a prevalence of either marine or fluvial sedi- ment input because the initial source of sediment in an estuary will most often be the fluvial waters of the estuary itself (Luternauer et al., 1995), but coastal processes of waves and tides are essential to mobilise and redistribute this sediment (Elliot, 1978). Hence, Luternauer et al. (1995) concludes that it is very difficult to determine whether sediment is being supplied directly from fluvial waters or if marine redistribution of the estuarine plume is more important. Without additional information regarding the fingerprinting of fluvial and marine sediment sources, e.g. geochemical data, the focus of attention has to remain on the environment of deposition, not sediment provenance, for the reconstruction of barrier integrity.

The bivariate plots of mean grain size against sorting provide a reliable means of reconstructing Holocene environmental change in coastal environments where barrier formation has had an important control on sedimentation. Although more detailed palaeoenvironmental data are available for the Guadalquivir, Guadalete and Scotney Marsh sites, the bivariate plot is an extremely powerful means of distinguishing between open- and closed-basin conditions where the standard granulometric approach merely provides evidence on depositional energy and the extent of sediment processing, and the palaeontological data describe variations in the marine influence irrespective of whether the depositional setting is open coast or tidal lagoon.

In the context of coastal evolution, it would seem appropiate to amend the model of Tanner (1991 a b) to take account of coastal change through sedimentation. From the estuarine environments studied above, it is possible to differentiate a new domain between the fluvial and closed basin environment domains of Tanner (1991a,b). The now domain represents the evolutionary sequence from open-to closed-basin conditions and, in our cases, represents the sedimentary facies between open estuary and filled or restricted estuary, and is situated, as would be expected, at the boundary between the domains defined previously (Fig. 10). Moreover, in some cases it is possible to distinguish sub-groups within this domain reflecting the different facies within the estuary through time. In a Late Pleistocene-Holocene sequence (as in Guadalete estuary), facies from the pre-Holocene valley fill sequence are well represented in the fluvial domain and the initial stages of estuarine formation defines 


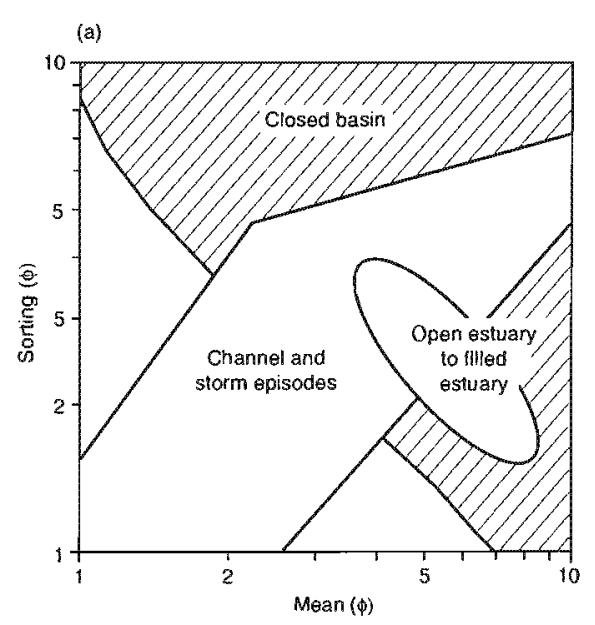

(b)

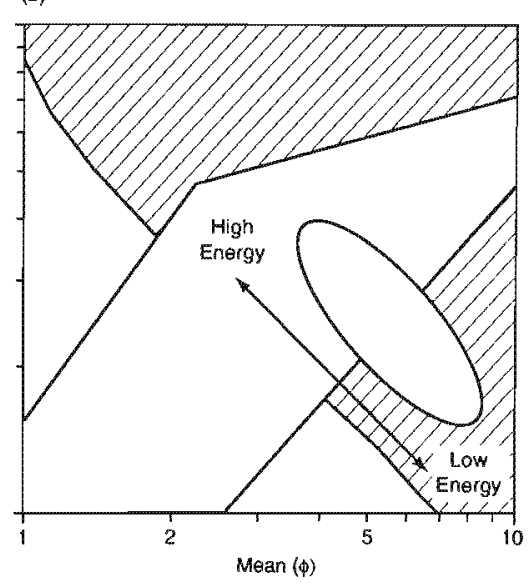

Fig. 10. (a) Proposed particle-size domains for estuarine sub-environments based on the bivariate plot (mean grain size against sorting) of Tamner (199/a,b) evolution of the particle-size domains interpreted in tems of changes in hydraulic conditions (depositional energy).

the new domain. Changes in this tendency, such as a sea-level fall, introduce new hydraulic conditions and displace the associated facies into the "channel" domain (fluvial or tidal channel). With the return of estuarine infilling conditions, the facies are again included in the new domain until the total filling of the estuary is approached, in which case the closedbasin domain is reached.

The record of barrier integrity and sediment flux, as revealed by the bivariate plot, is particularly important in the interpretation of the sedimentary records presented in this study where reduced rates of sea-level rise and changes in sediment flux have resulted in barrier progradation across an open estuary. Furthermore, the abruptness of changes in barrier integrity can be revealed using this approach, as can any aperiodic high-energy events, which have punctuated the record. Indeed, the approach of Tanner $(1991 \mathrm{a}, \mathrm{b})$ is also able to discriminate between lowfrequency high-magnitude events which are of marine (open-basin) or terrestrial (river) origin. Hence, a long-established technique is of potential application in addressing one of the more recent themes in coastal studies, i.e. the importance of abrupt events.

\section{Conclusions}

The suite statistics model of Tanner (1991a,b) provides an effective interpretative model in the con- text of Holocene back-barrier sedimentation under the influence of variable sediment supply, sea-level trends, barrier integrity and terrestrial inwash. The observed transitions between more open- and closedbasin environments as a consequence of barrier progradation and erosion, as interpreted from the bivariate plot, agree well with complementary palcoenvironmental data and the accepted sequences of coastal evolution. Furthermore, the bivariate plot enables the identification of fluvial inwash and barrier breaching/ overtopping events under high-energy conditions, which have punctuated the closed-basin conditions. With the new domain, the particle size data provide a means of distinguishing abrupt and gradual coastal change, and enable a more elegant palaeoenvironmental reconstruction rather than simple discrimination between two extremes.

The sedimentary records from SW Spain and SE England reflect changes in barrier integrity on the North Atlantic coasts during the Holocene as a function of sea-level rise and sediment flux. Tndeed, backbarrier infilling would appear to be the consequence of a positive sediment budget, primarily of fluvial origin, under conditions of reduced sea-level rise and increasing barrier progradation/integrity during the late Holocene. Although aperiodic high-energy geomorphic events have punctuated the record of backbarrier sedimentation, these abrupt events are relatively uncommon. Indeed, this low frequency would lend support to the preserved flood events being the 
result of extreme storms or tsunami, although less severe storms may have moulded the prograding barriers, particularly under conditions of low sea-level rise, and influenced the nature of back-barrier sedimentation in a less abrupt fashion.

\section{Acknowledgements}

This work has been supported by the Spanish DGES Projects PB98-0265 y PB98-0514; Fundación Areces Project "Cambios climálicos y variaciones del nivel del mar..." and Comunidad de Madrid postdoctoral grant. It is a contribution to IGCP 437 Project Coastal environmental change during sea-level highstands and INQUA Commission on sea-level changes. The authors also acknowledge Brett Gravel and the Romney Marsh Research Trust for their financial and logistical support during the course of this research. Thanks are also expressed to Dr. Antony Long for his assistance in supervision and interpretation, and to Sandra Mather for assistance in the production of final drafts of the figures.

\section{References}

Allen, J.R.L., 1990. Salt-marsh growth and stratification: a numerical model with special reference to the Seven Estuary, southwest Brilain. Mar. Geol. 95, 77-96.

Beuselinck, L., Govers, G., Poesen, J., Degraer, G., Froyen, L., 1998. Grain-size analysis by laser diffractometry: comparison with the sieve-pipette method. Catena 32, 193-208.

Buller, A.T., McManus, J., 1972. Simple metric sedimentary statistics used to recognise different environments. Secimentology $18,1-21$.

Carter, R.W.G., Orford, J.D., 1984. Coarse clastic barrier beaches: a discussion of their distinctive dynamic and morphosedimentary characteristics. Mar. Geol. 60, 377-389.

Carter, R.W.G., Forbes, D.L., Jennings, S., Orford, J.D., Shaw, J., Taylor, R.B., 1989. Barrier and lagoon coastal evolution under differing relative sea-level regimes: examples from Ireland and Nova Scotia. Mar. Geol. 88, 221-242.

Cooper, J.A.G., 1994. Lagoons and microtidal coasts. In: Carter, R.W.G., Woodroffe, C.D. (Eds.), Coastal Evolution: Late Quatemary Shoreline Morphodynamics. Cambridge Univ. Press, pp. 219-266.

Coulter Corporation, 1992. Coulter LS, User Manual

Crease, J., 1983. Extreme surge heights in the North Sea. MLAS News Bull. 6, 8-9.

Curray, IR., Emmel, F.J., Crampton, P.J., 1969. Holocene history of a strand plain, lagoonal coast, Nayarit, Mexico. In: Castana* ras, A.A., Phleger, FB. (Eds.), Coastal Lagoons. A Symposium. Universidad Nacional Autonoma de Mexico/UNESCO, Mexico City, pp. $63-100$.

Dabrio, C.J., Goy, J.L., Lario, J., Zazo, C., Borja, F., González, A., 1995. The Guadalete estuary during the Holocene times (Bay of Cadiz, Spain). NQUA Meditemranean and Black Sea Shorelines Subcommission Newsletter 17, 19-22.

Dabrio, C.J., Zazo, C, Goy, J.L., Sierro, F.J., Borja, F., Lario, J, González, J.A., Flores, J.A., 1999. Depositional history of esruarine infill during the Late Pleistocene-Holocene postglacial transgression. Mar. Geol. $162(2-4), 38]-404$.

Duck, R.W., 1994. Applications of the QDa-Md method of environmental discrimination to particle size analyses of fine sediments by pipente and sedigraph methods: a comparative sudy. Earth Surf Processes Land forms 19, 525-529.

Eddison, J, 1983. The evolution of barrier beaches between Fairlight and Hythe. Geogr. J. 149, 39-75.

Elliot, T., 1978. Clastic shorelines. In: Reading, H.G. (Ed.), Sedimentary Envionments and Facies. Elsevier, NY, pp. 143-177.

Folk, R.L., 1974. Petrology of Sedimentary Rocks. Hemphill, Austin, $\mathrm{TX}$.

Folk, R.L., Ward, W.C., 1957. Brazos River bas: a study in the significance of grain size parameters. J. Sediment. Petrol. 27 , $3-26$.

Friedman, G.M., 1961. Distinction between dune, beach and river sands from their textural characteristics. J. Sediment, Petrol. 31, $514-529$.

Friedman, G.M., 1967. Dynamic processes and statistical parameters compared for size frequency distribution of beach and rivers sands. J. Sediment. Petrol. 37, 327-354.

Friedman, G.M., 1979a Address of the retiring President of the Intemational Association of Sedimentologists: differences in size distributions of populations of particles among sands of various origirs. Sedimentology $26,3-32$.

Friedman, G.M., 1979b. Differences in the size distributions of populations of particles among sands of various origins: adm dendum to LAS Presicential Adriress. Sedimentology 26, $859-861$.

Friedman, G.M., Sanders, J.E., 1978. Principles of Sedimentology. Wiley, New York.

Gale, S.J., Hoare, P.G., 1991. Quatemary Sediments: Petrographic Methods for the Study of Unlithified Rocks. Wiley, New York $323 \mathrm{pp}$.

Goy, J.L., Zazo, C., Dabrio, C.J., Lario, J., Borja, F., Sierro, F., Flores, J.A., 1996. Global and regional factors controlling changes of coastlines in southern Doeria during the Holocene. Quat. Sci. Rev. $15(3-4), 1-8$.

Graff, J, 1977. The one in a hundred year tide. The Dock and Harbour Authority, 58, No. 682.

Green, R.D., 1968. The Soils of Romney Marsh. Soil Survey of England and Wales, Harpenden, Bulletir No. 4.

Griffiths, J.C., 1967. Scientific Methods in the Analysis of Sediments. McGraw-Hill, New York.

Hayes, M.O., 1979. Barrier island morphology as a function of tidal and wave regime. In: Leatheman, S.P. (Ed.), Barrier Islands. Academic Press, New York, pp. ]-27.

Hernández Molina, F.J., Somoza, L., Rey, J., Pomar, L., 1994. Late 
Pleistocene Holocene sediments on the Spanish continental shelves: model for very high resoluion sequence stratigraphy. Mar. Geol. 120, 129-174.

Klein, G.de V., 1972. A model for establishing palaeotidal range. Geol. Soc. Am. Bull. 82, 2585-2592.

Konert, M., Vandenberghe, J, 1997. Comparison of laser grain-size analysis with pipette and sieve analysis: a solution for the underestimation of the clay fraction. Sedimentology 44, 523-535.

Kraft, J.C., 1971. Sedimentary facies patterns and geologic history of a Holocene marine transgression. Geol. Soc. Am. Bull. 82, $2131-2158$.

Kraf, J.C., Chrzastwoski, M.J., 1985. Coastal stratigraphic sequen. ces. In: Davis, R.A. (Ed.), Coastal Sedimentary Environments, 2nd edn. Suringer-Verlag, New York, pp. 625-663.

Knumblein, W.C., 1934. Size frequency distributions of sediments. J. Sediment Petrol 4, 65-77.

Lario, J., 1996. Uitimo y presente interglacial en el área de conexión Atlántico-Mediterráneo: variaciones del nivel del mas, paleoclima y paleoambientes. PhD Thesis, Universidad Complutense de Madrid, 269 pp.

Lario, J., 1997. Is the Younger Dryas recorded in the estuarine sediments from south westem Deria Peninsula? NNQUA Mediterranean and Black Sea Shorelines Subcommission Newsletter $19,56-63$.

Lario, J., Zazo, C., Dabrio, C.J., Somoza, L., Goy, J.L., Bardají, T., Silva, P.G., 1995. Record of Recent Holocene Sediment Input on Spit Bars and Deltas of South Spain. In: Core, B. (Ed.), Holocene Cycles: Climate, Sea Levels, and Sedimentation. J. Coastal Res. Spec. Issue, vol. 17, pp. 241-245.

Lario, J., Zazo, C., Plater, A.J., Goy, J.L., Dabrio, C., Borja, F., Sierro, F.J., Luque, L., 2000. Particle size and magnetic properties of Holocene estuarine deposits from the Donana National Park (SW Tberia): evidence of gradual and abrupt coastal sedimentation. Z. Geomorphol. 45 (1), 33-54.

Long, A.J., Innes, J.B., 1995. The back-barrier and barrier depositional history of Romney Marsh and Dungeness, Kent, UK. J. Quat. Sci. 10, 267-283

Long, A., Plater, A.J., Waller, M.P., Irnes, J.B., 1996. Holocene coastal sedimentation in the Eastern English Channel: new data from the Romney Marsh region, United Kingdom. Mar. Geol. $136,97-120$.

Luternauer, JL., Alkins, R.J., Moody, A.I., Williams, H.F.L, Gibson, J.W., 1995. Salt marshes. In: Perillo, G.M.E. (Ed.), Geomorphology and Sedimentology of Estuaries. Dev. Sedimentol., vol. 53. Elsevier, The Netherlands, pp. 307-332.

Mason, C.C., Folk, R.L., 1958. Differentiation of beach, dure and aeolian flat envimonments by size analysis, Mustang Island, Texas. J. Sediment. Petrol. 28, $211-226$.

Mayewski, P.A., 1994. The Younger Dryas as viewed through the Summit Greenland ice cores. PAGES: News Int. Paleosci. Commun. $2(2), 3-4$.

MoCave, I.N., Bryant, R.J., Cook, H.F, Coughanour, C.A., 1986. Evaluation of a laser diffraction size analyser for use with nat ural sediments. J. Sediment. Petrol. 56, 561-564.

McManus, J., 1988. Grain Size determination and interpretation. In: Tucker, M. (Ed.), Techniques in Sedimentology. Blackwell, UK, pp. $63-85$
Moiola, RJ., Weiser, D., 1968. Textural parameters: an evaluation. J. Sediment. Petrol. 38, $45-53$

Nichols, M.M., 1989. Sediment accumulation rates and relative seam level rise in lagoons. Mar. Geol. 88, 201-219.

Plater, A.J., 1991. The Iate-Holocene evolution of Denge Marsh, south-east England: a stratigraphic, sedimentological and micropalaentological approach. Holocene 2 (1), 63-70.

Posamentier, H.W, Vail, P.R., 1988. Eustatic controls on clastic deposition: II. Sequence and systems tract models. In: Wilgus, C.K., Mastings, B.S., Kendall, C.G.St.C., Posamentier, H., Ross, C.A., Van Wagoner, J.C. (Eds.), Sea Level Changes. An Integrated Approach. SEPM Spec. Publ. vol. 42, pp. 125-154.

Reinson, G.E., 1992. Transgressive barrier island and estuarine systems. In: Walker, R.G., James, N.P. (Eds.), Facies Models: Response to Sea Level Change. GEOtext1, Geological Association of Canada, pp. $179-194$

Rodriguez Ramírez, A., Rodríguez Vidal, J., Cácenes, L., Clemente, L., Belluomini, G., Marnfa, L., Improta, S., De Andrés, J.R., 1996. Recent coastal evolution of the Donana National Park (SW Spain). Quat. Sci. Rev. 15 (8-9), 803-809.

Roy, P.S., 1984. New South Wales estuaries: their origin and evolution. Is: Thom, B.G. (Ed.), Coastal Geomorphology in Australia. Academic Press, Australia, pp. 99-121.

Roy, P.S., Crawford, E.A., 1981. Holocene geological evolution of the southern Botany Bay-Kumell region, central NSW coast. New South Wales Geol. Surv. Rec, 20, 159-250.

Roy, P.S., Cowell, P.J., Ferland, MA., Thom, B.G., 1994. Wavedominated coasts. In: Carter, R.W.G., Woodroffe, C.D. (Eds.), Coastal Evolution: Late Quaternary Shoreline Morphodynamics. Cambridge Univ. Press, Cambridge, pp. 121-186.

Shi, Z., 1993. Recent salmarsh accretions and sea level fluctuations in the Dyfi Estuary, central Cardigan Bay, Wales, UK. Geo-Mar. Lett. $13,182-188$.

Socci, A., Tanner, W.F., 1980. Little-known but important papers on grain-size analysis. Sedimentology 27, $231-232$

Spencer, C.D., 1997. The Holocene Evolution of Romney Marsh: a record of sea-level change in a back-barrier envimonment. Unpublished PhD thesis, University of Liverpool, $398 \mathrm{pp}$.

Spencer, C.D., Plater, A.J., Long, A.J., 1998. Rapid coastal change during the mid-to late-Holocene: the record of barier estuary sedimentation in the Romney marsh region, south-east England. Holocene 8 (2), $143-163$

Stanley, D.J., 1995. A global sea-level curve for the late Quatemary: the impossible cream? Mar. Geol. 125, 1-6.

Stanley, D.J., Warne, A.G., 1994. Worldwide initiation of Holocene marine delias by deceleration of sea-level rise. Science 265 , $228-231$

Stewart, H.B., 1958. Sedimentary reflections on depositional environments in Sar Miguel lagoon, Baja California, Mexico. Bull. Am. Assoc. Pet. Geol. 42, 2567-2618.

Syvitski, J.P.M., 1991. Principles, Methods and Application of Particle Size Analysis. Cambridge Univ. Press, Cambridge, $368 \mathrm{pp}$.

Syvitski, J.P.M., LeBlanc, K.W.G., Asprey, KW., 1991. Interlaboratory, interinstrument calibration experiment. In: Syvitski, J.P.M. (Ed.), Principles, Methods and Application of Particle Size Analysis. Cambridge Univ. Press, Cambridge, pp. 174-193. 
Tanner, W.F., 1991a. Suite statistics: The hydrodynamic evolution of the sediment pool. In: Syvitski, J.P.M. (Ed.), Principles, Methods and Applications of Particle Size Analysis. Cambridge Univ. Press, Cambridge, pp. 225- 236.

Tanner, W.F., $199 \mathrm{lb}$. Application of suite statistics to stratigraphy and sea-level changes. In: Syvitski, J.P.M. (Ed.), Principles, Methods and Applications of Particle Size Analysis. Cambridge Univ. Press, Cambridge, pp. 283-292.

Thorbjamarson, K.W., Nitrouer, C.A., DeMaster, D.J., Mckinney, R.B., 1985. Sediment accumulation in a back-barrier lagoon, Great Sound, New Jersey. J. Sediment. Petrol. 55, $856-863$.

Waller, M., Burrin, P.J, Marlow, A., 1988. Flandrian sedimentation and palaeoenvironments in Petf Level, the Brede and lower Rother valleys and Walland Marsh. In: Eddison, J., Green, C. (Eds.), Romney Marsh: Evolution, Occupation, Reclamation.
Oxford Univ. Comm. Archacol., Monogr., vol, 24. Oxbow Books, Oxford, pp. $3-30$.

Wame, A.G., Stanley, D.J., 1995. Sea-Level Change as Critical Factor in Development of Basin Margin Sequences: New Evidence from Late Quaternary Record. In: Core, B. (Ed.), Holocene Cycles: Climate, Sea Levels, and Sedimentation. J. Coastal Res. Spec. Issue, pp. 231-240.

Zazo, C., Goy, JL., Somoza, L., Dabrio, C., Belluomini, G., Impronta, S., Lario, J., Bardaji, T., Silva, P.G., 1994. Holocene sequence of relative sea level highstand-lowstand in relation to the climatic trends in the Atlantic-Mediterranean linkage coast: forecast for future coastal changes and hazards. J. Coastal Res. $10(4), 933-945$.

Zazo, C., Goy, JI., Lario, J., Silva, P.G., 1996. Littoral zone and rapid climatic changes during the last 20,000 years, The Beria study case. Z. Geomorphol. N.F. J02, 119-134. 